\title{
浮選における分散気ほうのサイズ分布について
}

- - - 浮選における気ほう負荷の研究（第 2 報）-—-

$$
\text { 正会員八嶋 三 郎* }
$$

\section{On the Size Distribution of $\mathrm{F}$ Flotation Bubbles}

- Study on the bubble loads in froth flotation-2-

\section{Saburo YASHIMA}

As the continuation of the previous report the author experimentally studied flotation bubbles by using experimental apparatus illustrated by Fig. 1 and obtained the following results.

(1) Shapes and sizes of bubbles obtained by photographic method under various frother concentration of T. F. No. 5 and MIBC are shown in Fig. 2 and 3.

(2) As illustrated by Fig. 4 mean diameter of bubbles, apparent specific gravity of pulp and volume of air drew into flotation machine gradually decrease with the increase of frother concentration. While. mean retention time of bubbles in flotation cell gradually increase with the decrease of bubble size.

(3) As shown in Fig. 5 depth of pulp have only little effect on size and shape of bubbles.

(4) Number and total surface of bubbles increase suddenly with the increase of frother concentration, these relations being illustrated by Fig. 6 .

\section{Notations}

$C$; frother concentration in $\mathrm{mg}, N_{b}$; number of measured bubbles, $D$; diameter of bubble in $\mathrm{mm}$, $\bar{D}$; mean diameter of bubbles in $\mathrm{mm}, \bar{\alpha}$; mean dimension ratio of bubbles, $\rho$; apparent specific gravity, $t$; mean stay time of bubbles in flotation cell in sec, $V$; air volume drew into flotation machine in $l / \mathrm{min}$, $h$; depth of pulp in $\mathrm{cm}, n_{1}$; number of bubbles produced in unit time in $1 / \mathrm{sec}, A_{1}$; total surface of bubbles produced in unit time in $\mathrm{cm}^{2} / \mathrm{sec}, n_{2}$; number of bubbles continuously contained in unit volume of pulp in $1 / l, A_{2}$; total surface of bubbles continuously contained in unit volume of pulp in $\mathrm{cm}^{2} / l$.

\section{1. まえがき}

著者は第 1 報1に掠いて気ほう表面に接着した鉱粒の 配列を大球の表面に㧍ける小球の配列と考えて，気ほう 表面における鉱粒の最密充てんに関する研究結果につい て述へ， 1 個の分散気ほらがその表面に接着しらる鉱粒 数には限界があることを明らかにした。この関係を用い ると, 与えられた浮選系において考えうる最大浮鉱量を 求め, これと実際の浮鉱量の関係から気ほう負荷, およ び気ほうの利用率を検討することができるわけであるが その基礎実験として浮選槽内における分散気活らのサイ ズ分布と相境界面面積a)などを求めてみた。以下にその 結果について報告する。

\section{2. 実 験 装置}

実験装置は第 1 図のようである。戝の( a ) 装置の全 体を示す側面图，(b)恃気ほう撮影装置，(c)は気ほう。 セルである。気ほうの撮影については Fahrenwald 22は

* 昭和38年 4 月 15 日受理

** 工博 東北大学助教授 工学部鉣山工学科
浮選槽中に液を満たしたビュレットを倒立させてその中 を上昇する気ほうを撮影し，Whelan らゔおよびFuerstenau ら $^{4}$ は浮選槽あるいは気ほうが上昇するセル外 から高速度撮影機で写し, Gründer ら ${ }^{5}$ およびBennett ら $\left.{ }^{6}\right)$ らは浮選槽内に気ほうが通過するスリットを有する 光学系を沈めて高速度撮影機で撮影し, 林 ${ }^{7)}$ はフラッシ ニランプを用いてガラス張り浮選槽外から撮影し， Sutherland $^{8)}$ はフラッシュランプによる撮影およびア ークランプの照射による高速度撮影を行なつた。著者は これらのうち Fahrenwald, 林および Sutherland の 方法を併用して撮影を行なつた。図の(1) 容量 $3 l$ の Denver 型浮選試験機で, インペラの直径 $80 \mathrm{~mm}$, 実験 は回転数 $1,740 \mathrm{rpm}$, 周速度 $435 \mathrm{~m} / \mathrm{min}$ で行なつた。 (2)は浮選機の電動機で 200watt, (3はスタンドパイプの 空気吸込口で，パイプ(4で空気流量計に接続してある。 スタンドパイプの上部はインペラの回転軸と気密になつ ている。(5)ガラス製気ほうセルで，図(b)のようにこ

a) 井上は交献 5) の摘録23) に括いて “相境界面面積” としたので これにしたがつた。 


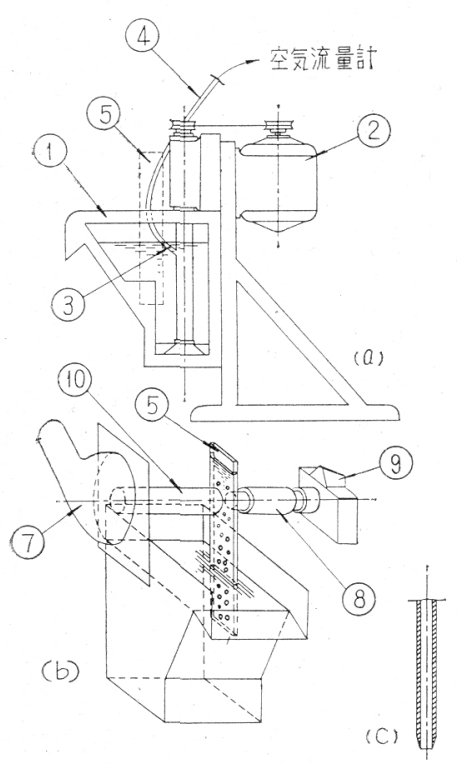

第 1 図 実験装置

の中を上昇する気核らを顕微鏡(8)を 通して写真機 $(9)^{b)}$ で撮影するc)。光 源に㳔(7)ストロボd学用いた。発 光時閒は $1 \mathrm{~m} \mathrm{sec}$ であり，(10)光を 導く中空円筒である决。

(c)は気ほうセルの先端部で気ほ うの停滞を防ぐためナイフエッジと した。気㭱らセルはスタンドパイプ と浮選槽側面との中央に雨入し七ル 先端が液面から槽底までの梁さの中 央に開口するよらに固定した。気ほ らセルは内面空閒の幅が 2, 4,6 mm のものを準備し，気ほらサイズに応 ごて使い分けた。水のみの場合と起 ほら剤濃度が低く気ほらサイズの粗 大な場合には顕微鏡を通して撮影することは困難なの で液面でストロボを発生させ，浮選槽側面のガラス空を 通じて気浪う接写した。気ほうの撮影と併行して浮選 機吸込空気量老測定し，必要に応じて浮選機密閉し吸 込，排出空気量の測定老行なつた。起ほら剂には高砂浮 鉱油 T.F. No. 5 と MIBC 在使用した。

\section{3. 実 験 結 果}

第2 四は気ほう写真の数例を示したもので，倍率およ

b) 主としてNIKON F 㱏,フイルムは A.S.A. 2000 子のを用いた。

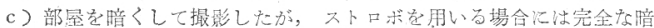
室でなくとも十分な撮影ができた。

d) KAKO S 2 型学使用乙坛。

e)この方法で丁度レンズの焦点深度の部分の気ほらのみがはのき

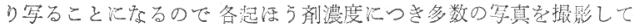
後述のサイズ分布を求めた。
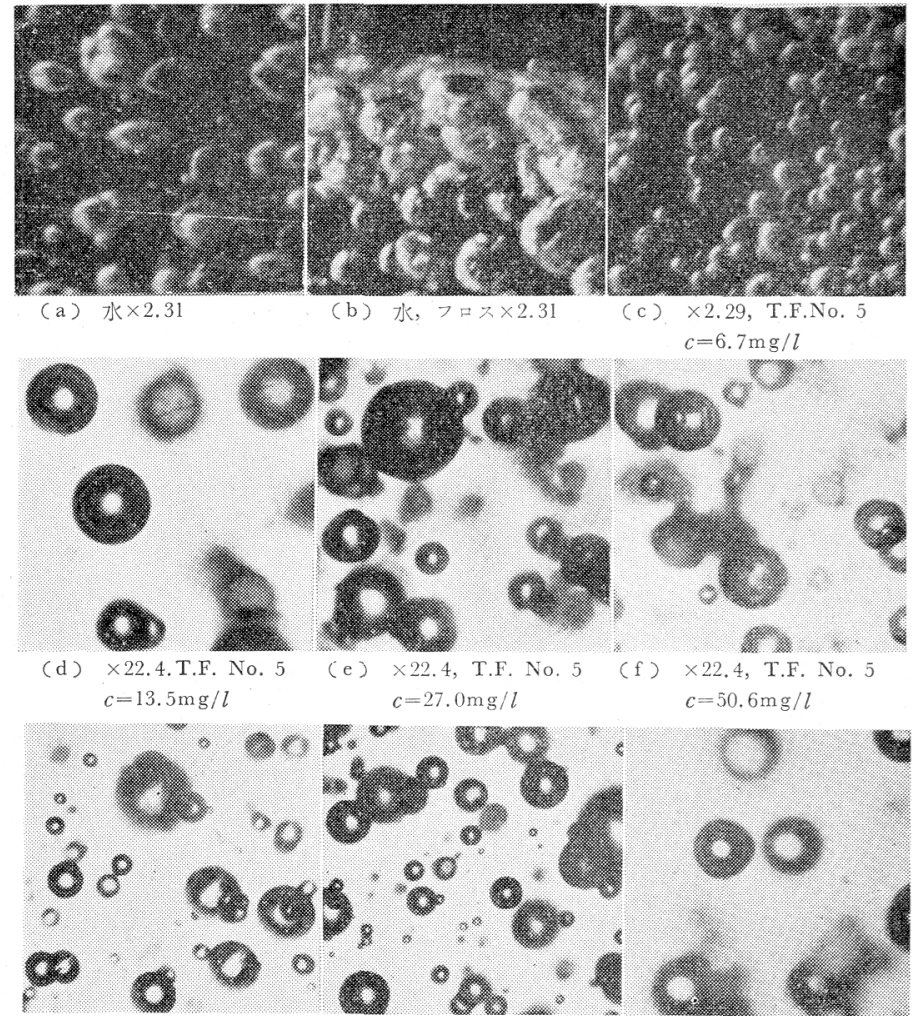

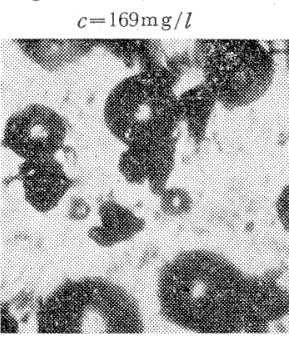

26 , T.F. No. 5 石炭の浮選 (h) $\times 22.4$ T.F. No. 5 $c=843 \mathrm{mg} / \mathrm{l}$

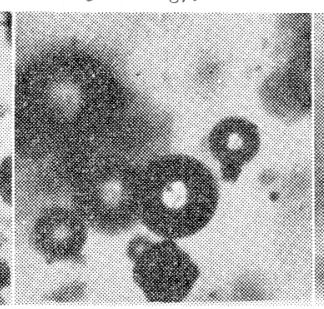

(k) $\times 26$, T.F. No. 5 硫化鈴鉱の浮遊 $c=19.9 \mathrm{mg} / \mathrm{l}$

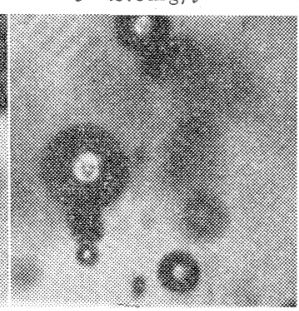

26, T.F. No. 5 方鈆錤の浮造
第2図気汪与の写真

び起活ら剂濃度 $c$ 定付記した。(a), ( b ) 注水のみの分 散気注らと液面に扮けるほらまつ層走示写真, (c) （）はＴ.F. No. 5 岩それぞれの濃度で添加したとき

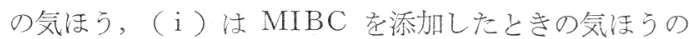
写真である。( $\mathrm{j}),(\mathrm{k}),(\mathrm{l})$ は, T.F. No. 5 女用 てそれぞれ石炭，硫化鉄鉱㧍よび方鉛鉱の浮選を行なつ たときの気ほらに鉣粒が接着した様子を捕えたもので参 考までに揭げた。

\section{$3 \cdot 1$ 気ほうの形状}

水のみの場合の気任らは粗大で形状も不規則であるが 起ほう剂が加えられると形状は球に近づき，気ほらが安 定して来るのが認められた。気ほうの最大径と最小径の 比をとりこ机寸法比 $\alpha$ とると，水のみの場合には平 均寸法比 $\bar{\alpha}=1.2$ であるのが, T.F. No. 5 の濃度 $c=$ 
$6.7 \mathrm{mg} / l$ では $\bar{\alpha}=1.1, c=13.5 \mathrm{mg} / l$ 以上では $\alpha=1.0$ と濃度の増加とともに球に近ゔいて来る。これらの気ほ 万寸法比は Whelan $ら^{9}$ ) の求めた結果と一致した傾向 を示している。

\section{2 気ほうのサイズ分布と気ほうサイズの起ほう剤} 濃度による变化

種々の起ほう剂濃度で気ほうのサイズ分布を調べた結 果は第 3 図のようである。図において $c$ 以前述のように 起ほう剂濃度, $n_{b}$ は数えた気ほうの数, 横朝の $D$ は気

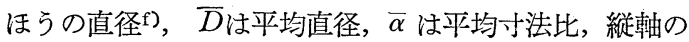
$f$ 汇頻度でパーセントで示した。起ほう剤濃度の増大と ともに次第にサイズが減少する傾向が見られるがこの関 係江第 4 図をみればさらに明らかである。図は横軸に $c$,

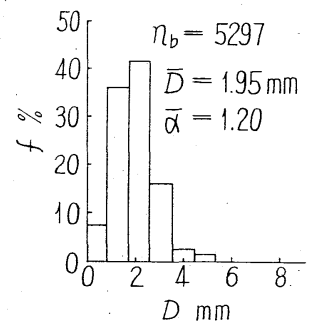

(a) 水の 0

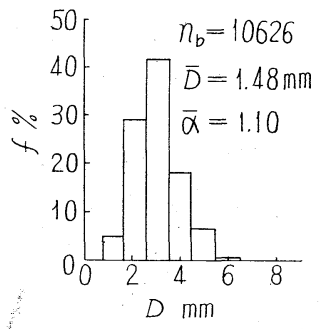

(b) T.F.No.5, $\mathrm{c}=6.7 \mathrm{mg} / \mathrm{l}$

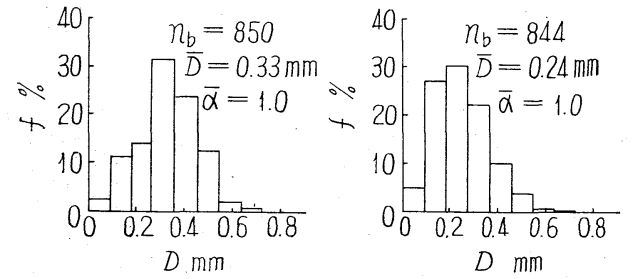

(c) T.F.No.5, $c=13.5 \mathrm{mg} / \mathrm{l}$ (d) T.F.No.5, $c=27.0 \mathrm{mg} / \mathrm{l}$

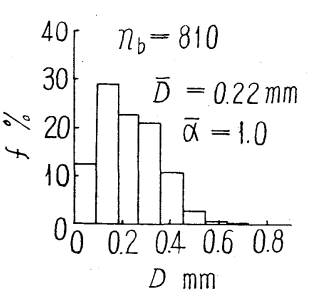

(e) T.F. No.5, $C=50.6 \mathrm{mg} / \mathrm{h}$

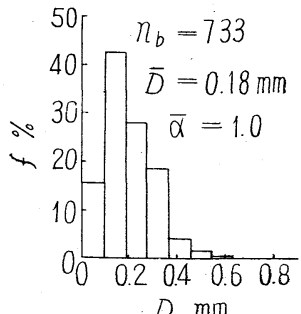

(f) T.F.No.5, $C=169 \mathrm{mg} / \mathrm{l}$

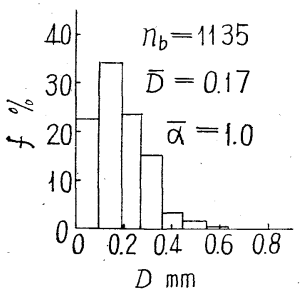

(g) T.F.N. $5, C=843 \mathrm{mg} / \mathrm{l}$

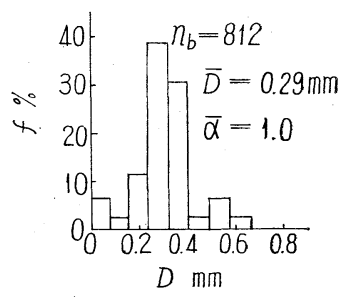

(h) MIBC, $C=19.9 \mathrm{mg} / \mathrm{l}$
$D:$ 気ほ 5 直径, $f:$ 頻度, $c$ : 起ほ 5 剂濃度, $n_{b}$ : 数兄た気

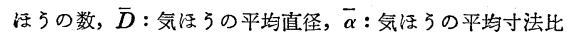

第 3 図気注うのサイズ分布
縦軸に $\bar{D}$ と分散系の比重 $\rho$ g)，分散気ほうの槽内平均滞 留時間 $t \mathrm{~h}$ )，および単位時間当たり吸込空気量 $V$ をとつ たものであるが,曲線市をみると T.F. No.5でもMIBC でも $\bar{D}$ は $c$ 増大とともにはじめ急激に減少するが， $c$ 約 $20 \mathrm{mg} / \mathrm{l}$ でほぼ一定值に達しそれ以上 $c$ が増大して も立の減少はきわめて緩慢となる。Fahrenwald ${ }^{10)}$, Gründer ${ }^{11)}$ Sutherland ${ }^{12)}$ らも主としてパイン油を使 用して気ほうサイズの測定を行なつているが，この中起 ほう剤濃度による気ほうサイズの変化を調べた最近の研

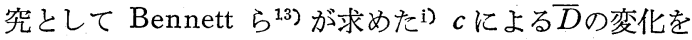
合わせて示すと図のようになり；本測定と同に傾向を示 していることがわかる。

\section{$3 \cdot 3$ 液面よりの深さによる気ほうサイズの変化}

次に液面よりの深さによる気ほう直径と寸法比の変化 を調べてみる之第 5 図のようになる。図は水のみの場合 と起ほう剂濃度 $c=6.7 \mathrm{mg} / l$. の場合について分散系を $0.43 \mathrm{~cm}$ ずつ 36 層に区切り各層ごとの $\bar{D} と \bar{\alpha}$ を示した ものである。液面からの深さんによる気ほうサイズの変 化は $h \doteqdot 8.6 \mathrm{~cm}$ 付近まではほとんで認められず一定で あるが，インペラの位置に接近するにつれて历が小とな り， が若干大となる傾向が認められ，この付近では激 しいかくはん作用のため気ほうが押しつぶされ，ゆがめ

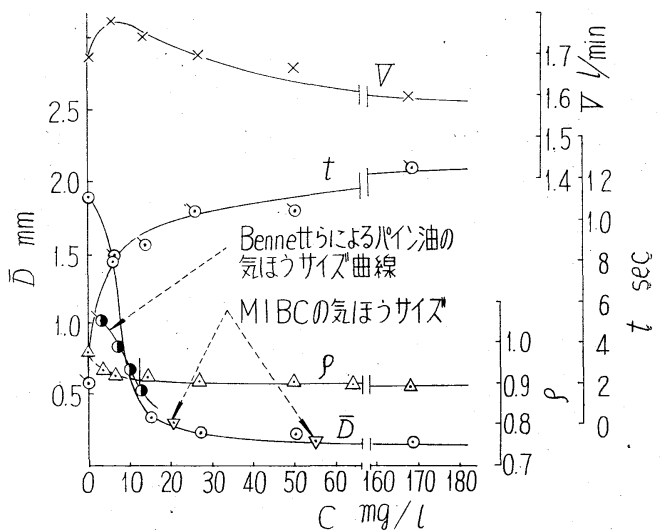

$\vec{D}:$ 平均気汪うサイズ, $c$ : 起活 5 剂濃度, $t$ : 浮選槽内平均 気ほ 5 滞留時間, $V$ : 吸込空気量, $\rho:$ 分散系比重

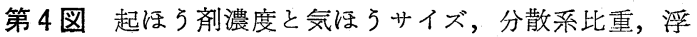
選槽内平均気注 5 滞留時間, 吸大空気量の関係

f）第 3 図に和いて水のみの場合など不規則な形状の気活 5 の分布は 気潘らの最大直径と最小直径との算術平均 $D_{1}$ をるて各気以うの 代表寸法として示したヒストグラムである。かかる気漂うの平均直 径 $\bar{D}$ を求めるのには, 不规則形状気潘 5 の形が一般に回転棈円体と みなし5るので上述のヒストグラムから代表寸法 $D_{1}$ の加重平均値 $\bar{D}$ を求め，これと平均寸法比 $\bar{\alpha}$ とから，気潘らを回転楕円体と見な したときの体積を算出し，これと同体積を有する球の直径を求めて 気湾了の平均㨁径 $\vec{D}$ とた。

g) 分散系を特殊比重ビン飞一定量吸出して測定した。

h) 分散系の比重 $\rho$ から槽内飞常時滞留する空気量を求めこれと単位 時間当たり吸込空気量とから算出した。

i ）Bennett らが求めた気ほらサイズ分布を示すヒストグラムから平 均值径 $\bar{D}$ を算出して $c$ との関係を示した。 


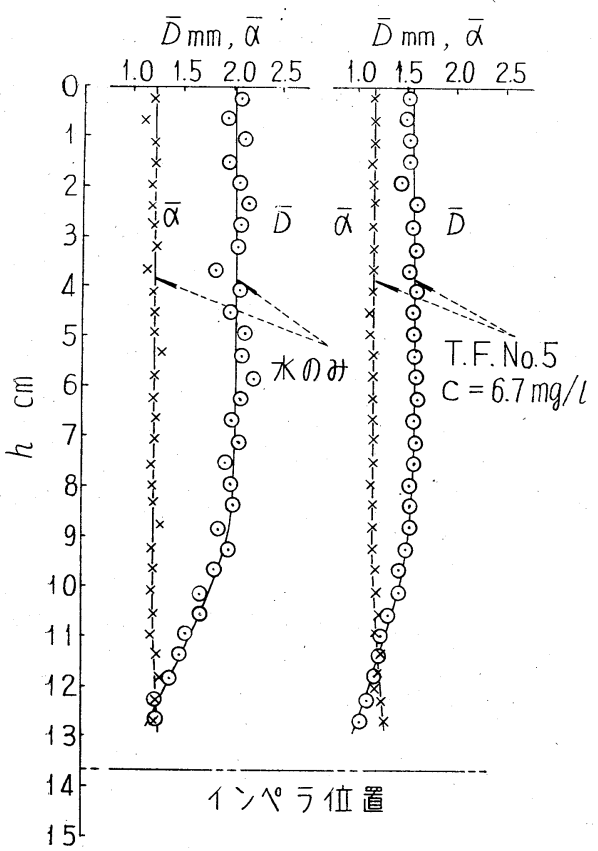

$h:$ 液面からの梁さ, $\bar{D}:$ 気泟 5 の平均直径, $\bar{\alpha}:$ 気活 5 の平均寸法比, $c:$ 起汪引剤濃度

第 5 図 液面からの深さによる気ほ5の变化 られて十分には生長しえない様子がうかがえる。しかし このような現象も起ほう剂濃度が低く，サイズの大きい 気ほうの場合にのみ顕著に認められるものであり，起ほ う剂濃度が高くなり，気ほうサイズが小となるにつれて 浮選槽内における気ほうの滞留時間が長くなり，気ほう の分散が均一となるので，深さによる影響は全く見られ なくなるように観察された。なお図および写真には示さ なかつたが, T.F. No. 5 に K.A. X を用いた結果は Gründer ${ }^{14}$ ) の結果と同様ザンセートの添加により気ほ らはさらに細かくなることが認められた。

\section{4 分散系の見掛比重と気ほうの滞留時間}

次に分散系の比重測定を行なつた結果は第 4 図の曲線 $\rho$ のようであうて,これも起ほう剤濃度と関係があり,濃 度が増大するとはじめ急に減少するが，それ以後はこの 傾向が緩慢となる。図の曲線 $t$ は比重測定結果から求め た槽内での平均気ほう滞留時間であつて，気ほうサイズ が粗大な場合には気ほう数が少なく，また個々の気ほう の浮力が大であるため上昇速度が速く，したがつて槽内 の滞留時間も短いが，気ほうサイズが小さくなると槽内 滞留時間も長くなる。これは気ほうの細粒化にしたがつ て浮力が小となり，一方槽内には中心部スタンドパイプ の付近には激しい下降流が，また壁面には上昇流があつ て $\mathbf{j}) ，$ 気ほう群はこの激し、渦流にまき込まれ，流れの 静かな部分へと脱出して液面に到達することができるま で，比較的長時閒槽内にとどまるようになるものと考え

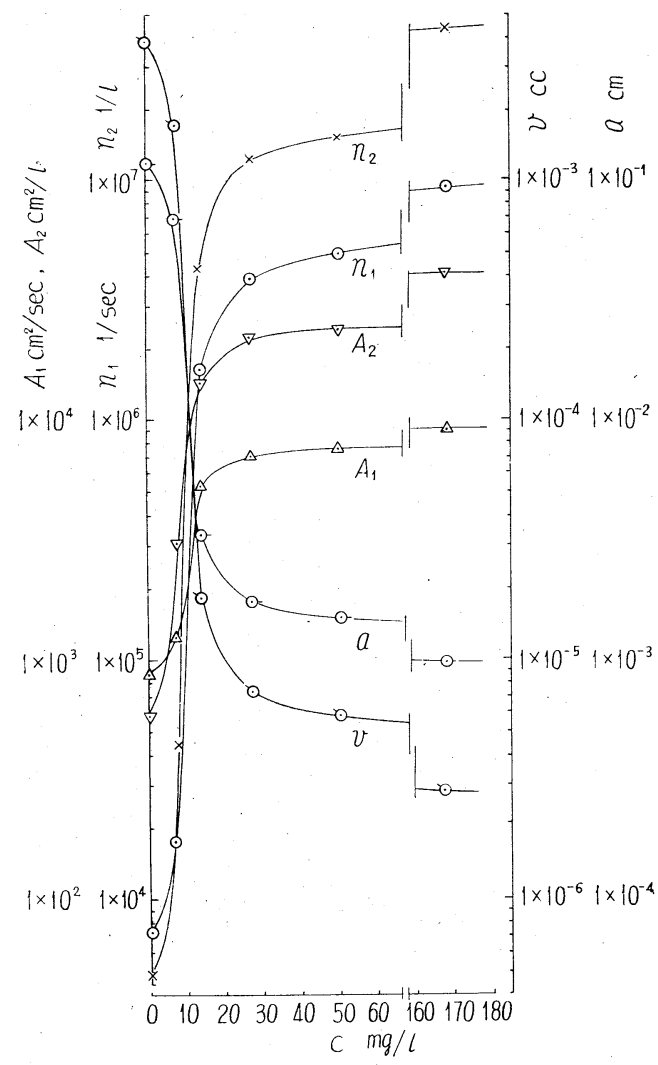

$n_{2}$ : 浮選槽内に存在する気注5数, 分散系 $1 l$ 当たり, $n_{1}$ : 単位時間当たり発生気注う数, $A_{2}$ : 浮選槽内の気汪う表面積 分散数 $1 l$ 当たり, $A_{1}$ : 単位時閒当たり発生する気活 万表面 積， $a$ : 気ほ 51 個当たり表面積, $v$ : 気注 51 個当たり体 積, $c:$ 起ほ 羭濃度

第6 図 起ほう剂濃度と発生気ほ5数, 気流う表面積など

られる。なお比重 $\rho$ は槽内の気ほうの分散がはなはだし く不均一となる $c \fallingdotseq 13 \mathrm{mg} / l$ 以下の濃度では分散系の見 掛比重として正確に求めることが困難となるので測定結 果を点線で示した。浮選機の吸込空気量と起ほう剤濃度 の関係は第 4 図の曲線Vのようで全般的には Worbel ${ }^{15}$ ) の研究と同様起ほう剂濃度の増大にともなつて気ほうが 細粒化するにしたがい減少する傾向を示しているが，起 ほう剂濃度の低い範囲で最大值を示し, 以後漸減する傾 向は林 ${ }^{16)}$ の測定結果と一致している。また図には示さな かつたが電動機大力の起ほう剤濃度による変化も Worbel ${ }^{17}$ ， 林 $\left.{ }^{18}\right)$ の研究結果と同様起ほう剤濃度の増大 とともにわずかではあるが減少する傾向にあり，起ほう 剤の添加によつてパルプの被破研性が増大するように認 められた。

\section{5 浮選槽内に単位時間当たり発生する気ほう個数 之相境界面面積}

j）槽内にゴムの細かい粒子を投入し，あるいは槽内に細く短い毛糸 の一端をはりつけてその動きによつて観察した。 
次に浮選機を密閉して吸込空気量と排出空気量の測定 k)を行ない，これらが等しい值を示すことを確認した後 浮選機を常態にもどし, 浮選槽内に発生する気ほうの数 と相境界面面積を気ほうの平均体積と吸込空気量を用い て Gründer ${ }^{19}$ および Bennett $ら^{20)}$ と同様の方法 で求めてみた。その結果は第 6 図に示すようである。横 軸は $c$, 縦軸の $a$ は気ほ5 1 個の平均表面積, $v$ はその 平均体積, $n_{1}$ は単位時間に発生する気ほう数, $A_{1}$ は単.位 時間に発生する相境界面面積， $n_{2}, A_{2}$ はそれぞれ常時浮 選槽内に存在する分散系 $1 l$ 当たりの気ほう数およびそ の相境界面面積である。これらの結果をみると $c$ の増大 にともなつて気ほうサイズが減少するにしたがい， $n_{1}$, $n_{2}, A_{1}, A_{2}$ ともにはじめ急激に増大するが；気ほうサイ ズが一定值に近づくとこれらも一定となり，一例として 起ほう剂濃度 $c=50.6 \mathrm{mg} / l$ で, 気ほうの平均直径 $\bar{D}=$ $0.22 \mathrm{~mm}$ の場合, $n_{1}=4.83 \times 10^{6} 1 / \mathrm{sec}, A_{1}=7,550 \mathrm{~cm}^{2} /$ sec, $n_{2}=15.2 \times 10^{6} 1 / l, A_{2}=23,700 \mathrm{~cm}^{2} / l$ となり, 非常 に膨大な数の気ほうと相境界面面積が生じていることが

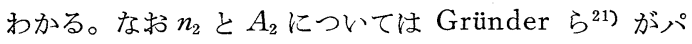
イン油を用いて測定した結果よりも一般に大きい值とな つているが，これは彼らの測定した気ほうサイズが，同 一cにおいて比較すると著者の值よりも大きい值を示し ていることに主たる原因があるものと思われる。

\section{4. むす び}

以上第 1 報にひきつづき浮選槽内における分散気ほう のサイズとその分布を求め, これから気ほう形状, 気ほ らサイズの起ほう剂濃度による変化, 液面からの涾度に
よる気ほうサイズの変化, 分散系の見掛比重と気ほうの 滞留時間, 槽内に発生する気ほう数と相境界面面積など を調べこれらの結果を従来の測定結果と比較した。気 ほうの写真測定については従来の研究結果よりも明膫な 撮影を行なうことができたように思う。これらの結果を 用い，浮選試験における実際の気ほら負荷を検討した実 験結果については次報に述べる予定である。

本研究を遂行するに当たり，ご指導をいただいた大山 正先生，ならびにご助言を賜わつた下飯坂潤三教授に深 く謝意を表する次第である。

\section{参考 文 献}

1）大山正・八鵬三郎：日鉱誌，77巻，872号，昭和 36 年 2 月, 94 100 ページ

2) A. F. Fahrenwald : E.M.J., Vol. 146, No. 10, Oct., 1945, pp. $94 \sim 95,155 \sim 156$.

3) P. F. Whelan \& D. J. Brown: Bull. Inst. Min. Met., Vol. 65, No. 591, Feb., 1956, pp. 181 192.

4) D. W. Fuerstenau \& C. H. Wayman: Min. Engng. Vol. 10, No. 6, June, 1958, pp. 694 699.

5) W. Gründer, W. Siemes u. J. F. Kauff mann: Erzmetall, Band IX, Heft 12, Dez., 1956, S. 559 608.

6) A. J. R. Bennett, W. R. Chapman \& C. C. Dell : Studies in Froth Flotation of Coal, 第 3 回国際選炭会議に括ける論文, June, 1958, Brnssels.Liege.

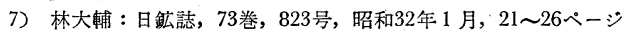

8) K. L. Sutherland : J. Phys. Chem. Vol. 52, pp. 394 425.

9 前出 3$),$ 10)前出 2$),$ 11) 前出5)，12)前出8)，13)前出6)，14)前 出5).

15) S. A. Worbel: Mine \& Quarry Engng. Sept., 1953, pp. $314 \sim 319$.

16）林大輔 : 日鉱誌, 78巻, 893号, 昭和37年11月, 809 816ペーシ

17) 前出 15 ).

18）林大輔：日釷茫志，73巻，829号，昭和 32 年 7 月

19）前出5)，20)前出6)，21) 前出5).

22）井上外志雄: 日鉣誌, 74 巻, 835号, 昭和 33 年 1 月50 53ペーシ, \{5)の摘録\}.

k ) 溶存空気の影犚を調べる目的で行なつた。

\section{著 紹 介}

\section{Rock-forming Minerals Vol. 1 5}

\section{1963 Longmans}

W. A. Deer, R. A. Howie and J. Zussman 著

鉣物の基本的な分類が結晶構造に あることは近年の常識である。この 著書では，従来よく用いられていた 元素鉱物, 酸化鉱物, 硫化鉱物等々の 分類を採らず，先ず，地殼を形作つ ている最も重要な鉱物の示す結晶構 造の基本形によつて 1 . Ortho-and Ring Silicates, 2. Chain Silicates, 3. Sheet Silicates, 4. Framework Silicates. の 4 大別にした がつて各冊を設け, Silicate 以外の さまざな結晶構造を持つものを
5. Non-Silicates として管 5 冊目に 取纒めてある点に一つの特街があ る。この反面, しかし, 造岩鉱物 に重点が置かれているため, NonSilicate minerals にさいてめる紙 数は比較的少なく，例えば，鉱石鉱 物として重要な硫化鉱物では, 黄鉄 鉱, 磁硫鉄鉱, 黄銅鉱, 方鉛鉱, 閃 亜鉛釷を揭げるに留つている。この 著畫の目的はこれで充分であり，ま たこれ以上求むべきではない。鉱物 各項の記載は結晶形態の”簡単な記
載, 物理性などの表記的記載を冒頭 に, 結晶構造の基本的な記述と問題 点の要約, 温度圧力条件の変化に対 応する相平衡 (固溶体, 多形の問題 を含む）物理性とくに光学的性質， 鑑定上の特徵, 岩石中(鉱石も含む) における他の鉱物との共生関係の順 になされている。最も力点がおかれ ているのは, 相平衡と共生関係であ るが，鉱物結晶の結晶構造の微かな 差異に至るまでの理解と, 天然の岩 石や鉱石中に打ける鉱物の産状の理 解とは，これらのことがらをさし措 いてはあり得ないことを思えば力点 をここに拈いた本書の勝れた意図が わかるであろう。著者は何れも世界 的な著名な学者であり, 最近の文献 まで選択よろしきを得て引用してあ る。(岩生)

$$
\text { 各冊 } \begin{array}{ll}
300 \sim 400 \text { ページ } \\
\\
¥ 4,000 \sim 6,000
\end{array}
$$

